\title{
Theoretical analysis of snow-dam decay
}

\author{
Zhaojun Xia AND Ming-Ko Woo \\ Department of Geography, McMaster University, Hamilton, Ontario L8S 4K1, Canada
}

\begin{abstract}
Snow dams have been observed in many stream channels in the Arctic and the sub-Arctic, but there is no theoretical analysis of their decay processes. These processes include snowmelt, seepage erosion, down-cutting, snowslope failure and flotation of the snow dam. Snowmelt can be determined by the energy balance. Seepage of water will cause serious erosion at the point where the stream or pond level in front of the dam intersects the dam face. Erosion by water overflowing the dam is due to down-cutting, under-cutting and thermal erosion. Down-cutting increases with discharge but decreases with the shear strength of the snow. Where a hydraulic jump occurs downstream of the dam, under-cutting can accelerate dam decay. Thermal erosion, depending mainly on water temperature, may be less significant than the previous two processes. Slope failure occurs when the driving forces exceed the resisting forces, and these are affected by snow property and snow load. When the stream or pond level downstream of the dam rises rapidly, the dam is prone to float. As peak flow often occurs during the break-up period, results of the theoretical study of the mechanisms of snow-dam decay will improve flood forecasting for Arctic streams.
\end{abstract}

\section{LIST OF SYMBOLS}

a Moment arm of sliding snow block $(\mathrm{m})$

A Area of snow in contact with stream water $\left(\mathrm{m}^{2}\right)$

$A_{\mathrm{s}} \quad$ Cross-sectional area of snow eroded by downcutting $\left(\mathrm{m}^{2}\right)$

$c \quad$ Constant of integration

$C \quad$ Cohesion of snow $\left(\mathrm{kg} \mathrm{m}^{-1} \mathrm{~s}^{-2}\right)$

d Water depth $(\mathrm{m})$

E Evaporation $\left(\mathrm{m}^{3} \mathrm{~s}^{-1}\right)$

$E_{\mathrm{d}} \quad$ Dynamic energy $\left(\mathrm{kg} \mathrm{m}^{-2} \mathrm{~s}^{-2}\right)$

$E_{\mathrm{p}} \quad$ Potential energy $\left(\mathrm{kg} \mathrm{m}^{-2} \mathrm{~s}^{-2}\right)$

$F_{\mathrm{B}} \quad$ Buoyancy force per unit area $\left(\mathrm{kg} \mathrm{m}^{-1} \mathrm{~s}^{-2}\right)$

$F_{\mathrm{q}} \quad$ Pressure normal to the dam face $\left(\mathrm{kg} \mathrm{m}^{-1} \mathrm{~s}^{-2}\right)$

$\mathrm{Fr} \quad$ Froude number

$F_{\mathrm{R}} \quad$ Resisting force, per unit area, against buoyancy $\left(\mathrm{kg} \mathrm{m}^{-1} \mathrm{~s}^{-2}\right)$

$F_{\mathrm{w}} \quad$ Pressure exerted by stream or pond against snow dam $\left(\mathrm{kg} \mathrm{m}^{-1} \mathrm{~s}^{-2}\right)$

Acceleration due to gravity $\left(\mathrm{m} \mathrm{s}^{-2}\right)$

Height of snow dam (m)

Water depth in reservoir behind snow dam $(\mathrm{m})$

Height at which seepage intersects dam face $(\mathrm{m})$

Height of water table in the snow dam (m)

Level of stream or pond in front of dam (m)

Hydraulic conductivity $\left(\mathrm{m} \mathrm{s}^{-1}\right)$

$k_{\mathrm{w}} \quad$ Thermal conductivity of water $\left(\mathrm{W} \mathrm{m}^{-1}{ }^{\circ} \mathrm{C}^{-1}\right)$
Distance between front and back faces of snow $\operatorname{dam}(\mathrm{m})$

Length of circular arc of sliding snow dam $(\mathrm{m})$
$L_{w} \quad$ Length of a segment of stream flowing over snow $(\mathrm{m})$

$m \quad$ Mass of water $(\mathrm{kg})$

$m_{\mathrm{s}} \quad$ Mass of snow $(\mathrm{kg})$

$M \quad$ Mass of sliding snow block $(\mathrm{kg})$

$P \quad$ Wetted perimeter (m)

$q \quad$ Seepage per unit width of snow dam $\left(\mathrm{m}^{2} \mathrm{~s}^{-1}\right)$

$Q \quad$ Discharge $\left(\mathrm{m}^{3} \mathrm{~s}^{-1}\right)$

$Q_{\text {c }} \quad$ Melt energy convected by stream water $\left(\mathrm{W} \mathrm{m}^{-2}\right)$

$Q_{\mathrm{E}} \quad$ Latent-heat flux $\left(\mathrm{W} \mathrm{m}^{-2}\right)$

$Q_{\mathrm{H}} \quad$ Sensible-heat flux $\left(\mathrm{W} \mathrm{m}^{-2}\right)$

$Q_{\mathrm{i}} \quad$ Inflow $\left(\mathrm{m}^{3} \mathrm{~s}^{-1}\right)$

$Q_{\mathrm{M}} \quad$ Melt energy $\left(\mathrm{W} \mathrm{m}^{-2}\right)$

$Q^{*} \quad$ Net radiation $\left(\mathrm{W} \mathrm{m}^{-2}\right)$

$r \quad$ Direction perpendicular to face of snow dam

$R \quad$ Radius of sliding circle $(\mathrm{m})$

$s \quad$ Direction parallel to face of snow dam

$S \quad$ Water storage $\left(\mathrm{m}^{3}\right)$

$t \quad$ Time (s)

$T$ Time duration (s)

$u^{*} \quad$ Shear velocity $\left(\mathrm{ms}^{-1}\right)$

$V \quad$ Velocity $\left(\mathrm{ms}^{-1}\right)$

$w \quad$ Width of sliding snow block (m)

$W \quad$ Width of snow dam (m)

$W_{\mathrm{d}} \quad$ Energy required to detach snow $\left(\mathrm{kg} \mathrm{m}^{2} \mathrm{~s}^{-2}\right)$

$W_{\mathrm{e}} \quad$ Energy required to entrain snow $\left(\mathrm{kg} \mathrm{m}^{2} \mathrm{~s}^{-2}\right)$

$x \quad$ Horizontal distance $(\mathrm{m})$

$z \quad$ Vertical distance or elevation (m)

$\alpha \quad$ Angle 


$\begin{array}{ll}\beta & \text { Angle } \\ \lambda & \text { Latent heat of fusion }\left(\mathrm{J} \mathrm{kg}^{-1}\right) \\ v & \text { Kinematic viscosity }\left(\mathrm{m}^{2} \mathrm{~s}^{-1}\right) \\ \phi & \text { Angle of internal friction of snow } \\ \rho & \text { Density of water }\left(\mathrm{kg} \mathrm{m}^{-3}\right) \\ \rho_{\mathrm{s}} & \text { Density of snow }\left(\mathrm{kg} \mathrm{m}^{-3}\right) \\ \rho_{\mathrm{s}}^{\prime} & \text { Density of snow below water table (i.e. } \\ & \text { saturated density) }\left(\mathrm{kg} \mathrm{m}^{-3}\right) \\ \sigma & \text { Stress normal to face of sliding snow block } \\ & \left.\text { (kg m } \mathrm{s}^{-1}\right) \\ \tau & \text { Shear stress }\left(\mathrm{kg} \mathrm{m} \mathrm{m}^{-1} \mathrm{~s}^{-2}\right) \\ \tau_{\mathrm{s}} & \text { Shear strength of snow }\left(\mathrm{kg} \mathrm{m}^{-1} \mathrm{~s}^{-2}\right) \\ \theta & \text { Water temperature }\left({ }^{\circ} \mathrm{C}\right)\end{array}$

\section{INTRODUCTION}

In the windswept areas of the Arctic and the sub-Arctic, a substantial quantity of snow may be blown into deeply incised valleys during the long winter. This snow accumulates to considerable thickness and is packed hard by the wind. During the break-up season of streams, this massive accumulation of snow, known as a snow jam, will obstruct the normal course of stream flow. Snow jams have been observed in many areas, from Greenland (Washburn, 1973) across the Queen Elizabeth Islands (Pissart, 1967; Woo and Sauriol, 1980; Heginbottom, 1984), to sub-Arctic North America (FitzGibbon and Dunne, 1981; Woo and Heron, 1987).

Of particular hydrological importance are snow dams which reach several metres high and span the width of the valley so that the meltwater run-off is impounded temporarily behind the dam until it decays. When this happens, a flood pulse is generated downstream, often reaching magnitudes unsurpassed during the rest of the year (Woo and Sauriol, 1981; Heginbottom, 1984). This effect is analogous to a mini-jökulhlaup, except that once the dam is breached all the impounded water will drain eventually. Despite its importance to the downstream discharge, the study of snow-dam decay has been limited to field observations. This paper provides a theoretical analysis of the various processes involved in dam decay. The purpose is to identify the variables which contribute significantly to the decay mechanisms so that in the future the processes can be evaluated quantitatively.

\section{SNOW-DAM CHARACTERISTICS}

Valleys in the High Arctic provide excellent examples of snow dams. There, the snow is cold, dry, dense and hard. Average density of snow at Resolute reaches $350 \mathrm{~kg} \mathrm{~m}^{-3}$ and its average hardness exceeds $20000 \mathrm{~kg} \mathrm{~m}^{-2}$ (Williams, 1957). In exposed areas, wind slabs acquire densities of $400-500 \mathrm{~kg} \mathrm{~m}^{-3}$. Sub-freezing. temperatures for over 9 months in each year prevent the occurrence of melt events and, despite the low winterprecipitation characteristics of a polar desert environment, the cumulative winter snowfall, accentuated by pronounced drifting, can produce very deep snow cover in some topographically sheltered areas.

Along the length of incised valleys, the snow is often unevenly distributed, creating transverse ridges which block off the valley to enclose troughs. An example of such snow ridges and troughs is given in Figure 1. In this
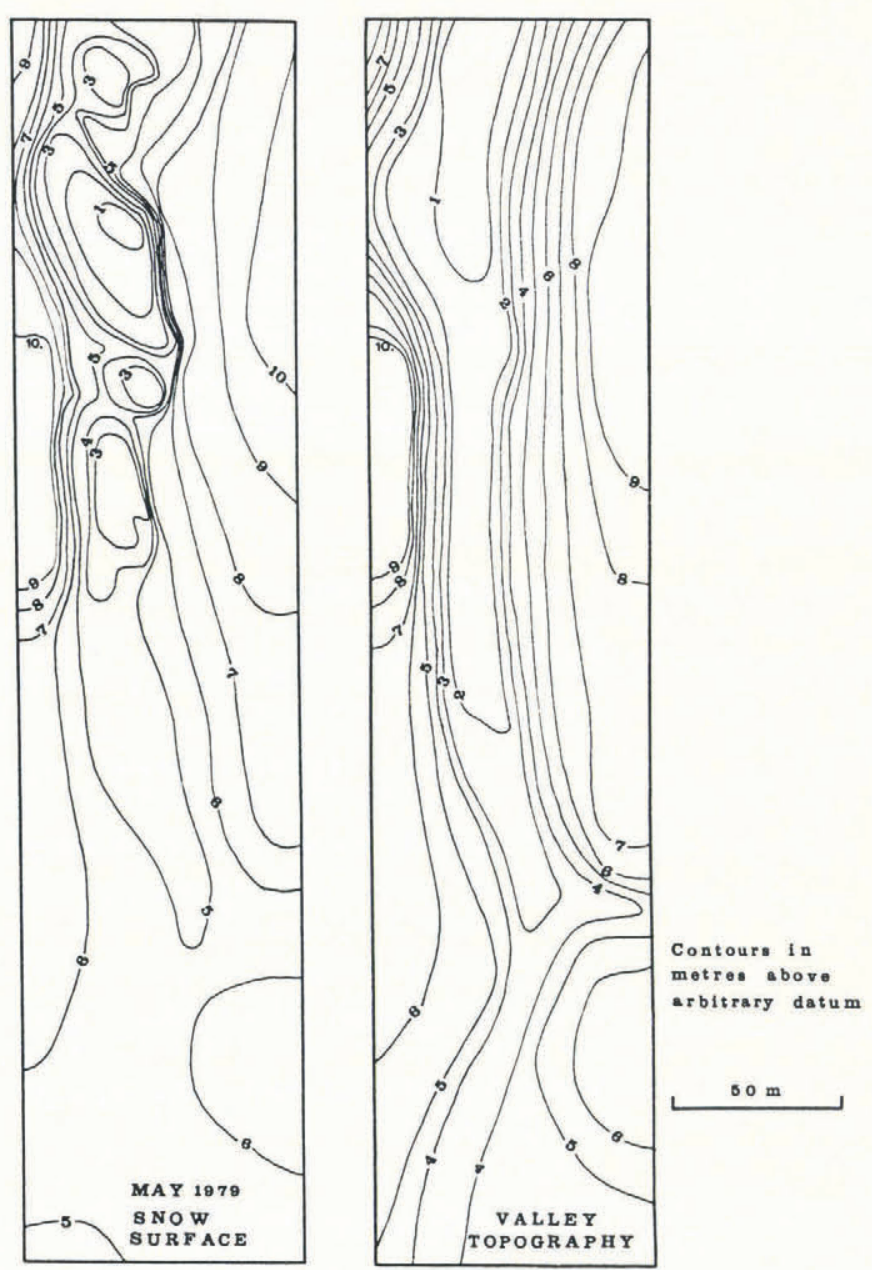

Fig. 1. Typical dimensions of snow dams in an incised valley, Resolute, N.W.T., Canada.

valley, near Resolute, Cornwallis Island, Arctic Canada, the snow ridges recur at similar locations from year to year, reflecting the control of the interaction between the prevailing winter wind and the valley topography. These ridges are $2-6 \mathrm{~m}$ high and act as snow dams that retain meltwater during the snowmelt season (Fig. 2).

A snow dam is a massive accumulation of snow that forms a ridge across the valley, enclosing a trough behind it to become a temporary reservoir when the trough is filled by meltwater run-off. The dam sits on top of a relatively impervious, frozen substrate and usually has steep front and back walls. In longitudinal profile, the crest ranges from being sharp to being fairly broad, sometimes with several minor drift ridges on top of the crest. In the following discussion, a simple profile is generalized for the dam, consisting of a back face (facing the reservoir it impounds), a front face and a narrow crest. The snow that comprises the dam is assumed to be uniform and homogeneous, has a certain permeability, but is hard and dense because it is wind-packed. The stream bed it rests on is impervious because of its frozen state.

\section{DAM-DECAY PROCESSES}

The decay of snow dams was observed and recorded by time-lapse photography for several years (between 1977 and 1988$)$ at Resolute $\left(75^{\circ} \mathrm{N}, 95^{\circ} \mathrm{W}\right)$. This record al- 


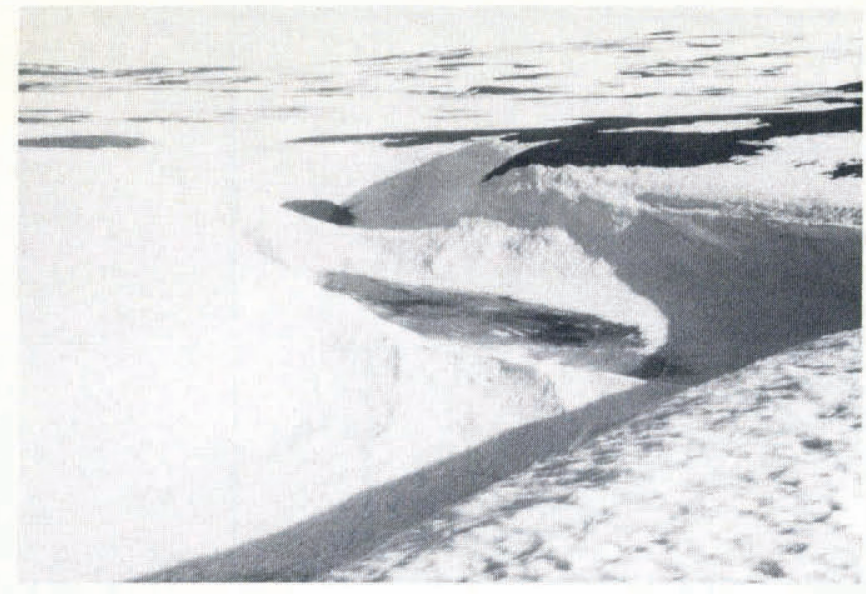

Fig. 2. Snow dams in a valley near Resolute. Photograph was taken on 15 June 1981 when meltwater began to infill the troughs behind the dams (photograph by M.-A. Dubreuil). These dams recur at similar locations each year (cf. Figs 3 and 7).

lowed a qualitative appreciation of the timing and relative magnitude of the dam-decay processes. The main processes involved included snowmelt, erosion at the seepage points along the front face, down-cutting and under-cutting of the dam, rotational sliding of the snow mass and flotation of the dam. Not all of the processes occur at every snow dam and each process operates at a different rate, making the decay patterns different from one dam to another.

However, prediction of the decay mechanisms can be achieved through pre-melt surveys of the snow properties, the geometry, the topographic setting and the local microclimate of individual snow dams along the valleys. The equations presented in the following sections will enable the dam-decay rates to be quantified.

\section{SNOWMELT}

The melting of Arctic and sub-Arctic snow cover has been dealt with previously (Weller and Holmgren, 1974; Price and Dunne, 1976; Marsh and Woo, 1985). The melt process can best be described by the energy balance:

$$
Q_{\mathrm{M}}=Q^{*}+Q_{\mathrm{H}}+Q_{\mathrm{E}}+Q_{\mathrm{R}}+Q_{\mathrm{C}}
$$

where $Q_{\mathrm{M}}$ is the energy available for melt, comprising the net radiation $\left(Q^{*}\right)$, sensible- $\left(Q_{\mathrm{H}}\right)$ and latent-heat fluxes $\left(Q_{\mathrm{E}}\right)$, energy from rainfall $\left(Q_{\mathrm{R}}\right)$ and from stream water $\left(Q_{\mathrm{C}}\right)$. Ground-heat flux is not included here because it is a heat-loss term and does not contribute to melt (due to the intense sub-freezing conditions of the ground).

The various terms of the energy balance will not be discussed in detail here. The radiation component will vary considerably in the valley, depending on the orientation of the dam with respect to the changing position of the shadows. The sensible- and latent-heat fluxes may be lower in the valleys because of the lower wind speed. Rain-convected heat is less important because of the low precipitation in the Arctic. Heat convected by stream water will be dealt with in a later section. When $Q_{\mathrm{M}}$ is

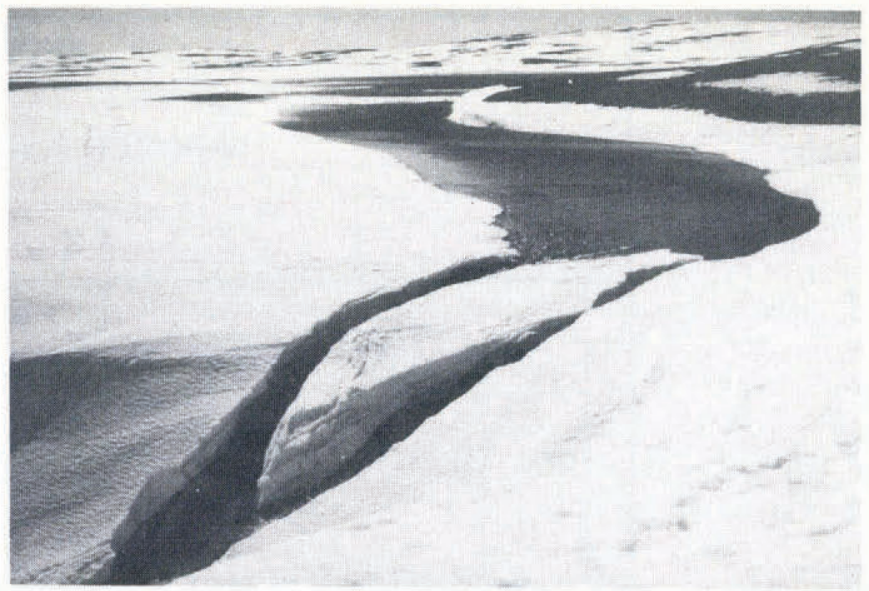

Fig. 3. Temporary ponds formed behind snow dams being drained as the lower dam was breached by down-cutting, and the upper dam was floated on 7 July 1978. (Photograph by R. Heron.)

obtained, the rate of loss in snow depth can be computed by $Q_{\mathrm{M}} / \rho_{\mathrm{s}} \lambda$, where $\rho_{\mathrm{s}}$ is snow density and $\lambda$ is the latent heat of fusion.

Compared with most parts of a drainage basin, the incised valleys where the snow dams occur are likely to receive less melt energy. The deep snow cover also contains a large cold content which consumes part of this energy during snow ripening and thus delays its melt. It is common to observe meltwater from the thinner snow cover of the basin slopes discharged to the valleys where the presence of snow dams intercepts this flow to create temporary ponds along the valleys (Fig. 3). Some of the meltwater that seeps to the bottom of the snow dam refreezes upon contact with the sub-freezing stream bed or the cold snow, forming a layer of ice at the base of the snow dam (Woo and Heron, 1981).

\section{EROSION BY SEEPAGE}

Meltwater from the snow dam and from the adjacent slopes will percolate to the base of the snow dam to develop a saturated zone. Then, as a reservoir is formed behind the dam, the impounded water will raise the water level of this saturated zone. Based on the Darcy flow law, the velocity $(V)$ is

$$
V=-k(\mathrm{~d} z / \mathrm{d} x)
$$

and the discharge per unit width along the dam face is

$$
q=-k z(\mathrm{~d} z / \mathrm{d} x)
$$

where $k$ is the hydraulic conductivity of the saturated snow, and $\mathrm{d} z / \mathrm{d} x$ is the hydraulic gradient (Fig. 4). Collecting terms and integrating, we have

$$
q x=-0.5 k z^{2}+c .
$$

For the boundary condition of $x=0$, and $z=H$, where $H$ is the water depth in the reservoir, the constant of 


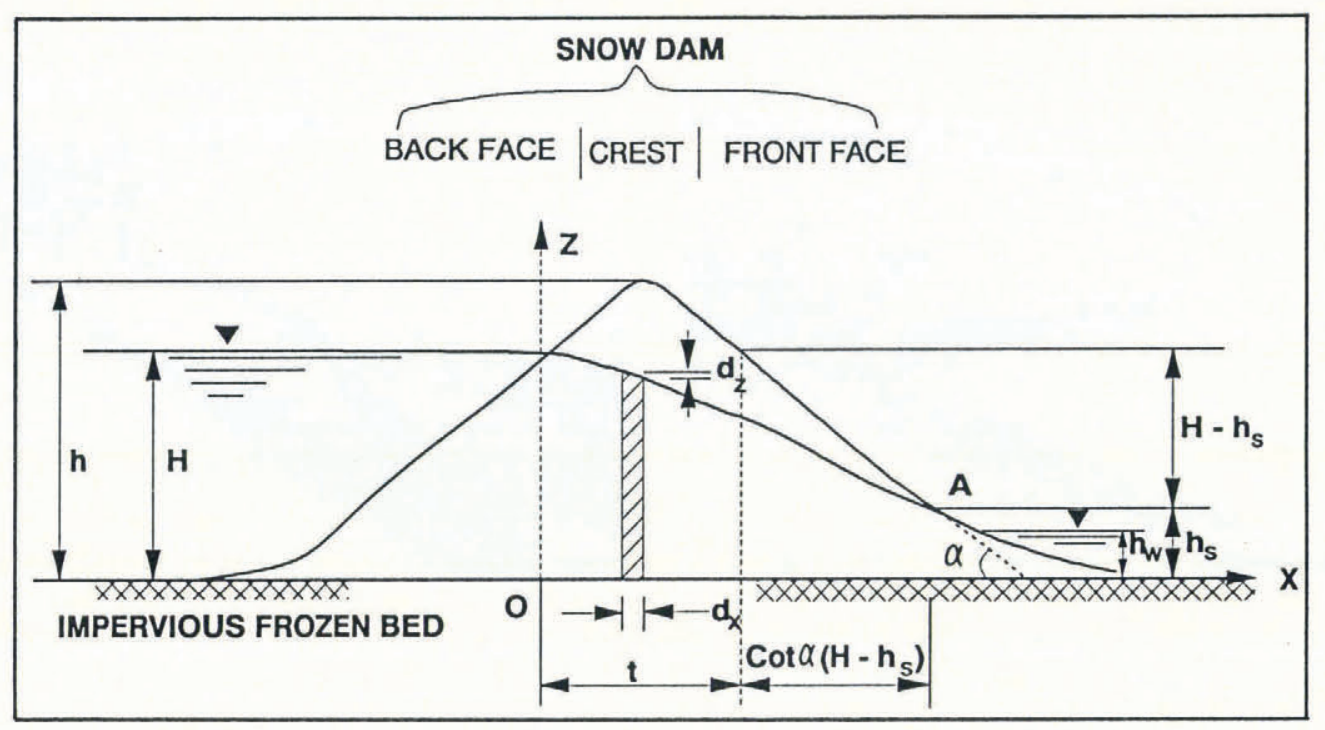

Fig. 4. Profile of a snow dam showing the water table and seepage zone.

integration is

$$
c=0.5 k H^{2}
$$

and

$$
q=k\left(H^{2}-z^{2}\right) / 2 x .
$$

Equation (6) can then be used to determine the seepage face along the front of the dam.

\section{Seepage from dam face}

Seepage from snow dams follows processes similar to those for earth dams (Jumikis, 1984) with the important difference that the frozen substrate beneath the snow dams is impermeable to water movement. Thus, the slopes of failure cannot extend beyond the base of the snow dams.

No seepage will emerge from the front of the dam while the water is moving through the dry zone in the snow. Should a saturated zone be fully developed, the highest elevation of the seepage face on the front of the dam (position A in Figure 4) is where the water table intersects the dam surface. Approximating the front of the dam by a straight face, with a slope angle of $\alpha$ and substituting into Equation (6), the dam geometry gives the following discharge at the horizontal distance where the upper boundary of seepage intersects the dam face $\left(h_{\mathrm{s}}\right.$ in Figure 4$)$

$$
q=k\left(H^{2}-h_{\mathrm{s}}^{2}\right) /\left\{2\left[l+\cot \alpha\left(H-h_{\mathrm{s}}\right)\right]\right\} .
$$

Here, $l$ is the horizontal distance between where the elevation of the water level in the reservoir intersects the back and the front faces of the dam.

At the location where $z=h_{\mathrm{s}}$, discharge is at a max-. imum. In other words, $\mathrm{d} q / \mathrm{d} h_{\mathrm{s}}=0$, and $\mathrm{d}^{2} q / \mathrm{d} h_{\mathrm{s}}{ }^{2}<0$. The first derivative is

$$
\begin{gathered}
\mathrm{d} q / \mathrm{d} h_{\mathrm{s}}=k\left\{-2 h_{\mathrm{s}}\left[l+\cot \alpha\left(H-h_{\mathrm{s}}\right)\right]+\cot \alpha\left(H^{2}-h_{\mathrm{s}}{ }^{2}\right)\right\} \\
/\left\{2\left[l+\cot \alpha\left(H-h_{\mathrm{s}}\right)\right]^{2}\right\} .
\end{gathered}
$$

For this to be zero, either the numerator is zero or the denominator is infinite. For the snow dam, $\cot \alpha$ is ob- viously not infinite, nor is the denominator. As $k$ is positive, it follows that

$$
\cot \alpha\left(H^{2}-h_{\mathrm{s}}{ }^{2}\right)-2 h_{\mathrm{s}}\left[l+\cot \alpha\left(H-h_{\mathrm{s}}\right)\right]=0 .
$$

The solution to this quadratic equation shows that for $q$ to be at a maximum

$$
h_{\mathrm{s}}=(H+l / \cot \alpha)-\left[(H+l / \cot \alpha)^{2}-H^{2}\right]^{0.5} .
$$

The negative root is used to give a physically real quantity for $h_{\mathrm{s}}$.

Equation (9) reveals that, to accommodate the maximum amount of seepage, the vertical extent of the seepage zone at the dam face depends on the dam geometry and the water-level elevation of the reservoir. The rate of discharge, however, is a function of the hydraulic conductivity (Equation (7)), and therefore is dependent on the physical properties of the snow.

\section{Potential seepage-failure zone}

We consider the general case where a snow dam has impounded a reservoir with water-level elevation $H$, and a

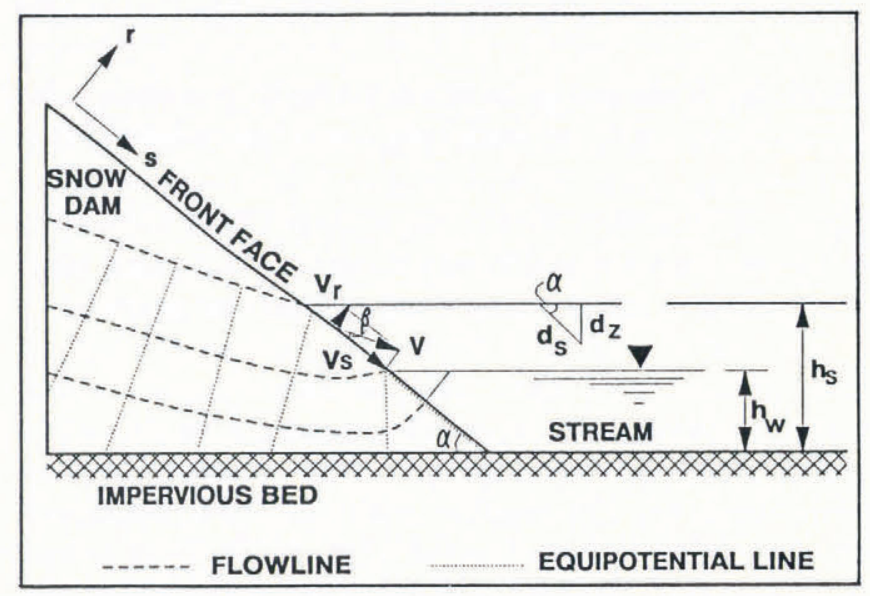

Fig. 5. Location of potential seepage failure zone. 
stream or a pond in front of it with a water-level elevation $H_{\omega}$, which is lower than the height of the upper limit of the seepage zone, $h_{\mathrm{s}}$ (Fig. 4). Below $H_{\omega}$, the dam face itself is an equipotential line, so that the direction of seepage out of the dam is perpendicular to it (Fig. 5). The velocity of seepage at the point $h_{\mathrm{s}}$ is

$$
V=k \sin \alpha
$$

and the direction is parallel to the front face of the dam. If we consider two vectors, one parallel to the front face of the dam (direction $s$ ) and the other perpendicular to the face (direction $r$ ), the zone below $h_{\omega}$ will have $V_{\mathrm{r}}=V$ and $V_{\mathrm{s}}=0$.

Above $h_{\omega}$, the position of the flowlines is such that they intersect the dam face at an angle $\beta$, which changes from $0^{\circ}$ at the uppermost seepage point, where the water table cuts the dam face, to $90^{\circ}$ at $h_{\omega}$. Then

$$
\begin{aligned}
& V_{\mathrm{r}}=V \sin \beta=V_{\mathrm{s}} \tan \beta \\
& V_{\mathrm{s}}=V \cos \beta=k \sin \alpha .
\end{aligned}
$$

Thus, at elevation $h_{\mathrm{s}}$ on the dam face, $V_{\mathrm{r}}=0$ and $V_{\mathrm{s}}=V$. As $\beta$ changes from $0^{\circ}$ to $90^{\circ}, \tan \beta$ changes from 0 to $\infty$, and so does $V_{\mathrm{r}}$. In reality, this velocity cannot be infinite but will take on extremely large values.

The pressure of the seepage water in the direction normal to the dam face $\left(F_{\mathrm{q}}\right)$ is

$$
F_{\mathrm{q}}=\rho V_{\mathrm{r}}^{2} / 2
$$

where $\rho$ is the density of the water. Clearly, this pressure increases continuously from the elevation $h_{\mathrm{s}}$ to the elevation $h_{\omega}$. Below the water line at $h_{\omega}$, the water in the stream or pond exerts an opposing pressure to seepage, and this pressure $\left(F_{\omega}\right)$ is

$$
F_{\omega}=\rho g\left(h_{\omega}-z\right), \quad z<h_{\omega}
$$

where $g$ is acceleration due to gravity and $z$ is elevation above the bed.

The net pressure of the seepage water is

$$
F=F_{\mathrm{q}}-F_{\omega} .
$$

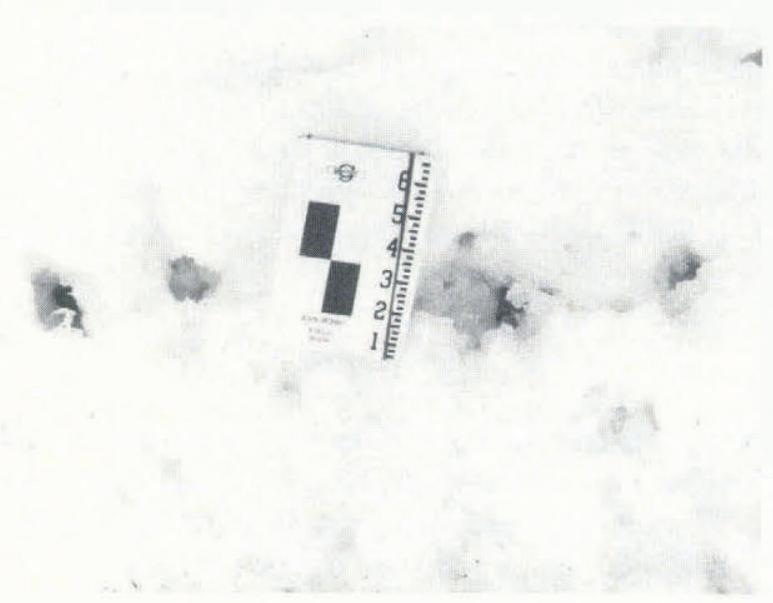

Fig. 6. Pipes developed in snow, exposed on the front face of a snow dam.
$F$ reaches a maximum at the water line as shown in Figure 5. Surrounding this maximum point is a zone where the pressure exceeds some critical level where erosion can be initiated. This is the zone where piping has been observed to occur. Once piping develops, velocity increases further, and the strength of the dam is weakened at those points. This, in turn, accelerates erosion at such points (Fig. 6).

\section{RUPTURE BY OVERFLOW}

Water level in the reservoir usually rises faster than the attainment of a fully saturated zone in the dam, leaving a dry zone at the top part of the dam. A continuous supply of water from upstream, $Q_{\mathrm{i}}$, may then exceed the storage capacity $(S)$ of the trough behind the dam, and overflow occurs when

$$
\left[\int_{0}^{T} Q_{\mathrm{i}} \mathrm{d} t-\int_{0}^{T} E \mathrm{~d} t-\int_{0}^{T} Q_{\mathrm{s}} \mathrm{d} t\right]>S
$$

where $E$ is evaporation, $Q_{\mathrm{s}}$ is seepage discharge $\left(Q_{\mathrm{s}}=\right.$ $q W$, with $W$ being the width of the dam) and $T$ is time elapsed since infilling of the trough began. Evaporation is much less important than $Q_{\mathrm{i}}$ and $Q_{\mathrm{s}}$, and the rupturing of a snow dam by overflow may be attributed to the following processes.

\section{Down-cutting of snow dam}

As water overflows the dam, down-cutting and entrainment of snow will take place. Consider a segment of the snow dam of length $L_{\mathrm{w}}$, with a wetted perimeter $P$. At the upper and the lower ends of this segment, the elevations are $z_{1}$ and $z_{2}$; the water depths are $d_{1}$ and $d_{2}$; and the velocities are $V_{1}$ and $V_{2}$. When snow detachment and snow entrainment occur along this segment, the continuity equation is

$m\left(g z_{1}+g d_{1}+V_{1}{ }^{2} / 2\right)=m\left(g z_{2}+h d_{2}+V_{2}{ }^{2} / 2\right)+W_{\mathrm{d}}+W_{\mathrm{e}}$

with $m$ being the mass of water, $W_{\mathrm{d}}$ and $W_{\mathrm{e}}$ being the energy to initiate snow detachment and for snow entrainment, respectively. Snow detachment, both as individual grains or as small blocks, occurs when the shear stress of water exerted on the snow $(\tau)$ overcomes the shear strength of the snow $\left(\tau_{\mathbf{s}}\right)$, or

$$
W_{\mathrm{d}}=\tau A L_{\mathrm{w}}=\tau_{\mathrm{s}} A L_{\mathrm{w}}=\tau_{\mathrm{s}} P L_{\mathrm{w}}{ }^{2}
$$

where $A=P L_{\mathrm{w}}$ is the snow surface in contact with the flowing water. For snow entrainment, the velocity of the snow in the water is assumed to be the same as the flow velocity, and the acceleration along the segment $L_{\mathrm{w}}$ is $\left(V_{2}{ }^{2}-V_{1}{ }^{2}\right) / 2 L_{\mathrm{w}}$. Then

$$
\begin{aligned}
W_{\mathrm{e}} & =m_{\mathrm{s}}\left[\left(V_{2}^{2}-V_{1}^{2}\right) / 2 L_{\mathrm{w}}\right] L_{\mathrm{w}} \\
& =m_{\mathrm{s}}\left(V_{2}^{2}-V_{1}^{2}\right) / 2 .
\end{aligned}
$$

Here, $m_{\mathrm{s}}$ is the mass of snow entrained. Substituting Equations (18) and (19) into Equation (17),

$$
\begin{aligned}
m_{\mathrm{s}}\left(V_{2}^{2}-V_{1}^{2}\right) / 2+\tau_{\mathrm{s}} P L_{\mathrm{w}}{ }^{2} & \\
& =m g\left[\left(z_{1}-z_{2}\right)+\left(d_{1}-d_{2}\right)\right]+m\left(V_{1}^{2}-V_{2}^{2}\right) / 2
\end{aligned}
$$

or 
$m_{\mathrm{s}}=2\left[m g\left(z_{1}-z_{2}+d_{1}-d_{2}\right)-\tau_{\mathrm{s}} P L_{\mathrm{w}}{ }^{2}\right] /\left(V_{2}^{2}-V_{1}^{2}\right)-m$.

The mass of water passing over the segment in time $T$ is

$$
m=\rho Q T
$$

with $Q$ being the discharge and $\rho$ being the water density. The amount of snow entrained from this segment is

$$
m_{\mathrm{s}}=\rho_{\mathrm{s}} L_{\mathrm{w}} A_{\mathrm{s}}
$$

where $\rho_{\mathrm{s}}$ is snow density and $A_{\mathrm{s}}$ is the cross-sectional area of the snow being eroded from the segment. Putting Equations (21) and (22) into Equation (20), the rate of snow eroded along the segment is $L_{\omega} A_{\mathrm{s}} / T$, which can be obtained by:

$$
L_{\mathrm{w}} A_{\mathrm{s}} / T=\left(\rho / \rho_{\mathrm{s}}\right) Q\left[\left(E_{\mathrm{p}}-\tau_{\mathrm{s}} P L_{\mathrm{w}}{ }^{2}\right) / E_{\mathrm{d}}-1\right]
$$

where $E_{\mathrm{p}}=m g\left[\left(z_{1}+d_{1}\right)-\left(z_{2}+d_{2}\right)\right]$ is the potential energy and $E_{\mathrm{d}}=m\left(V_{2}{ }^{2}-V_{1}{ }^{2}\right) / 2$ is the dynamic energy. It should be noted that $E_{\mathrm{p}}$ is positive because of the natural stream gradient. In terms of flow velocities, Equation (19) shows that $V_{2}<V_{1}, W_{\mathrm{e}}<0$ and deposition takes place. When $V_{2}=V_{1}, W_{\mathrm{e}}=0$ and there should be no snow entrainment. Equation (23) suggests that for entrainment to occur, the ratio between the dynamic energy and the difference between the potential and detachment energies must exceed 1.0. When this happens, down-cutting is proportional to discharge, $Q$.

\section{Under-cutting at the foot of the snow dam}

When water tumbling down the dam face reaches the foot of the snow dam, the large velocity may produce a hydraulic jump. The occurrence of the jump depends on the Froude number $(\mathrm{Fr})$ :

$$
\operatorname{Fr}=V /(g d)^{\frac{1}{2}}
$$

where $V$ is velocity, $g$ is acceleration due to gravity and $d$ is water depth. Based on information from open-channel hydraulics (Henderson, 1966), a gradual change from $\mathrm{Fr}=1.0$ to 1.7 manifests itself by a slightly ruffled water surface. As Fr exceeds 1.7, small rollers develop on the surface and, when Fr reaches between 2.5 and 4.5, an oscillating form of hydraulic jump occurs, with the entering jet flowing intermittently near the bottom and then along the surface, producing waves that will severely scour the foot of the dam. This leads to undercutting of the dam face (Fig. 7).

\section{Thermal erosion}

At the initial stage of break-up, water temperature is close to $0^{\circ} \mathrm{C}$ but, as more stream bed is exposed upstream of the snow dam, the stream water may be warmed above $0^{\circ} \mathrm{C}$. This water convects heat to the dam to induce thermal erosion. As the flow is fully turbulent, one can assume complete thermal mixing above the laminar sublayer, so that the upper boundary of the sub-layer has a water temperature of $\theta$, where $\theta>0$, and at the snow surface the temperature remains at $0^{\circ} \mathrm{C}$. Assuming further that the temperature gradient is linear within this thin sub-layer, the heat flux to the snow, $Q_{\mathrm{c}}$, is

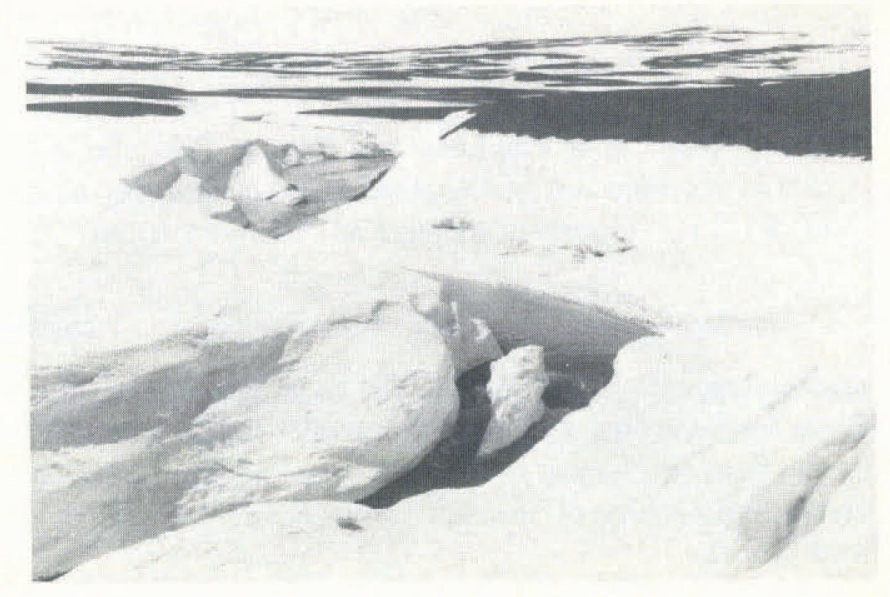

Fig. 7. Under-cutting of snow dam as flow plunges down the face of the dam (2 July 1988). Snow-slope failure indicated by large tension cracks such as those at the lower right.

$$
Q_{\mathrm{c}}=-k_{\mathrm{w}} \mathrm{d} \theta / \mathrm{d} z
$$

where $\mathrm{d} \theta / \mathrm{d} z$ is the thermal gradient and $k_{\mathrm{w}}$ is the thermal conductivity of water. The depth of thermal erosion caused by such heat transfer is

$$
Q_{\mathrm{c}} / \rho_{\mathrm{s}} \lambda \approx k_{\mathrm{w}} \theta /\left(\rho_{\mathrm{s}} \lambda z_{1}\right)
$$

where $\rho_{\mathrm{s}}$ is snow density, $\lambda$ is the latent heat of fusion, and $z_{1}$ is the thickness of the laminar sub-layer which has been experimentally determined as

$$
z_{1}=11.6 \nu / u^{*}
$$

where $\nu$ is the kinematic viscosity and $u^{*}$ is the shear velocity (Chang, 1988). From Equation (26), it is clear that thermal erosion is directly proportional to the water temperature and is inversely related to the laminar sub-layer thickness which, according to Equation (27), decreases as the shear velocity increases.

\section{FAILURE OF SNOW SLOPE}

Snow-slope failure occurs as translational or rotational movement of the ruptured snow block downward and outward from the dam (Fig. 7). For a potentially sliding snow block, the driving force is $M g \sin \beta$, with $M$ being the mass of the snow block, and $\beta$ is the angle between the vertical and the direction of normal stress (Fig. 8). The resisting force is $\tau_{\mathrm{s}} w L$, where $w$ is width of the block, $L$ is the length of the sliding arc and the shear strength of the snow $\left(\tau_{\mathrm{s}}\right)$ is

$$
\tau_{\mathrm{s}}=\sigma \tan \phi+C .
$$

Here, $C$ is the cohesion of snow, $\phi$ is the angle of internal friction and $\sigma$ is the normal stress on the rupture surface.

Stability of a snow slope can be indicated by the factor of safety $K$ which is a ratio of the resisting moment and the driving moment of the sliding snow mass:

$$
K=\tau_{\mathrm{s}} w L R / a M g \sin \beta
$$




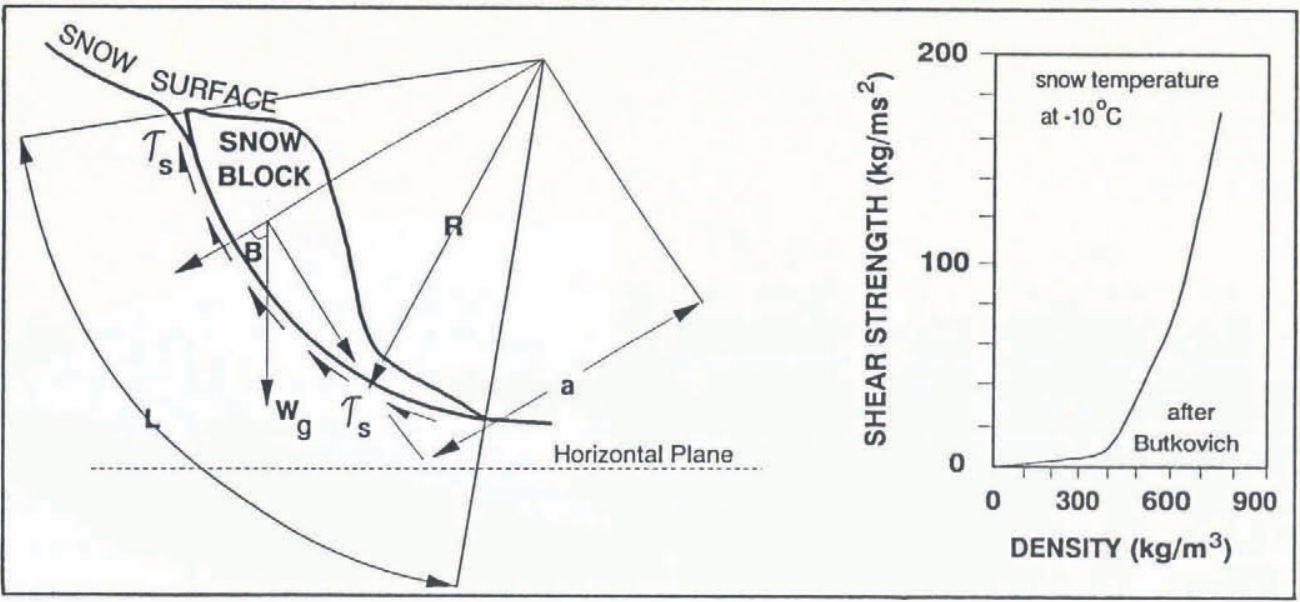

Fig. 8 Potential failure geometry on snow slope and relationship between shear strength and snow density (after Butkovich, quoted by Mellor (1963)).

where $R$ is the radius of the sliding arc and $a$ is the moment arm of the snow mass. When $K<1$, the snow block ruptures. Such failure may be gradual or sudden, and can occur along any part of the snow dam.

From Equation (29), the main considerations for snow-slope failure are: (1) $\tau_{\mathrm{s}}$ which is dependent on density (Fig. 8), temperature and grain-size texture of the snow (Mellor, 1963). (2) The slope angle, because the steeper the slope, the larger is $\sin \beta$. (3) The weight of the snow block $M$, which is subject to continuous increase as meltwater is added to the snow.

\section{FLOATING OF SNOW DAM}

At a late stage of decay, some dams have been observed to float (Fig. 3). Consider the buoyancy and its opposing forces acting on a unit column of the snow dam. Let the height of this snow column be $h$, the elevation of the water table be $h_{\mathrm{u}}$ and the depth of stream or pond water in front of the dam be $h_{\mathrm{w}}$. The buoyancy force $\left(F_{\mathrm{B}}\right)$ is

$$
F_{\mathrm{B}}=\rho g h_{\mathrm{w}}
$$

and the resisting force exerted by the snow $\left(F_{\mathrm{R}}\right)$ is

$$
F_{\mathrm{R}}=\rho_{\mathrm{s}} g\left(h-h_{\mathrm{u}}\right)+\rho_{\mathrm{s}}^{\prime} g h_{\mathrm{u}}+C
$$

where $\rho_{\mathrm{s}}$ and $\rho_{\mathrm{s}}^{\prime}$ are the snow densities for the zones above and below the water table in the snow dam and $C$ is cohesion at the base of the dam. To lift this column, $F_{\mathrm{B}} \geq F_{\mathrm{R}}$ and the critical stage is when

$$
F_{\mathrm{B}}=F_{\mathrm{R}}
$$

or

$$
\rho h_{\mathrm{w}}=\rho_{\mathrm{s}}\left(h-h_{\mathrm{u}}\right)+\rho_{\mathrm{s}}^{\prime} h_{\mathrm{u}}+C / g .
$$

Thus, water level of the stream or pond below the dam has to reach the critical depth of

$$
h_{\mathrm{w}}=\left[\rho_{\mathrm{s}}\left(h-h_{\mathrm{u}}\right)+\rho_{\mathrm{s}}^{\prime} h_{\mathrm{u}}-C / g\right] / \rho .
$$

Several points are to be noted: (1) Since the snow columns are adjoined, floating of the snow dam requires that the buoyancy force is sufficient to lift the column which exerts the maximum resistance to flotation. This position is often located upstream of the centre of the dam where both $h$ and $h_{\mathrm{u}}$ are large to yield the maximum $F_{\mathrm{R}}$. (2) The formation of an ice layer at the base of the snow dam (due to refreezing of meltwater) increases the cohesion, and hence $F_{\mathrm{R}}$. (3) The deeper the water is in front of the dam, the larger the buoyancy. This situation often happens when another snow dam downstream impounds a small pond.

\section{DECAY OF SNOW-DAM SEQUENCE}

Snow dams sometimes occur in sequence along a valley. During the melt season, the dam at the upstream end of the sequence is often the first to be filled with water. Then, one by one, a series of reservoirs will be formed. As time goes by, when the first snow dam ruptures, water will be released to the next reservoir to raise its water level suddenly, causing its decay to accelerate. This flood wave cascades downstream so that a series of dam failures follows (e.g. Woo and Sauriol, 1980, p.47). Most of such dam failures are due to erosion by overflow. The flotation of a snow dam accelerates water release to the dams below, hastening the destruction of the lower dams.

If water is supplied to the area between several snow dams before they rupture, the elevation of the water level in the lower reservoir will influence the failure of the upstream dam. This is particularly noticeable when the downstream dam fails first, suddenly dropping the tailwater level for the upstream dam. The internal saturated water pressure is then at a maximum but the resistance force is greatly reduced. Such instability will cause part of the upper dam to slide.

\section{DISCUSSION}

Field measurement of snow-dam decay rates provides useful information on the magnitudes of various degradation processes, but it gives only limited insight into the variables governing these processes. A theoretical treatment allows the assessment of the relative importance to the controlling variables, so that pertinent 

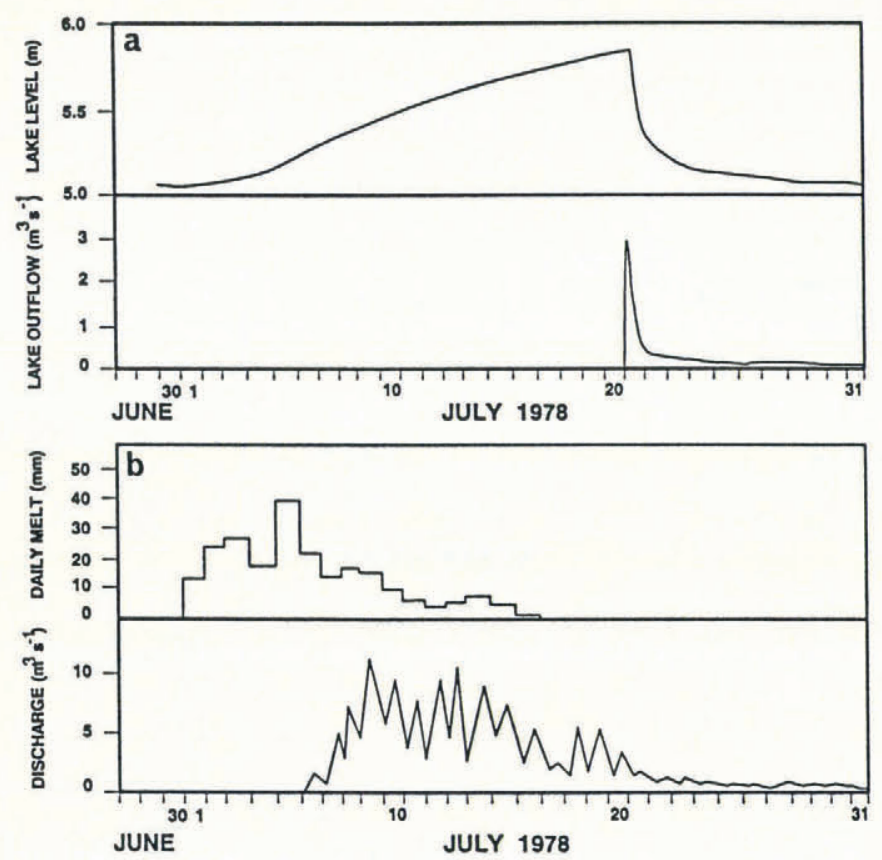

Fig. 9. Snow-dam effects on stream flow. (a) Lake level before, during and after bursting of snow dam, and outflow hydrograph showing flood pulse. (b) Delay of stream-flow response to basin snowmelt events.

field observations can be made in the future to predict the rates of snow-dam decay.

The inclusion of snow-dam decay in the modelling of Arctic stream break-up will improve considerably the prediction of snowmelt run-off. Two examples illustrate this point:

(1) The outlet of a small lake near Resolute is regularly blocked by a snow dam at the end of winter (Woo and others, 1981). This dam, about $4 \mathrm{~m}$ high, prevents the snow meltwater (from a $1.5 \mathrm{~km}^{2}$ basin) from flowing out of the lake, and raises the water level continuously until the dam bursts. When this happens, an extreme flood occurs downstream, reaching a magnitude unexpected of a catchment of such a limited size. For example, in 1978 , the peak outflow averaged $10.0 \mathrm{~m}^{3} \mathrm{~s}^{-1}$ over a $2 \mathrm{~h}$ period, and in 1979 the peak was $3.1 \mathrm{~m}^{3} \mathrm{~s}^{-1}$. In such a case, the timing of outflow is governed by the decay of the dam and the magnitude is controlled by the dam height. (2) In McMaster basin (area $33 \mathrm{~km}^{2}$ ), stream flow always lags snowmelt run-off, even after a substantial proportion of the meltwater has been delivered from the slopes to the snow-filled channels (Fig. 9). The initiation of stream flow is controlled by channel processes rather than slope snowmelt activities. High flows usually occur after the melt rate for the basin as a whole has peaked. The timing of high flows is related to the decay of a series of major snow dams to release much of the stored meltwater downstream (Fig. 10).

Annual peak flow in nival-regime rivers of the Arctic (Church, 1974) frequently occurs during the period when the channels are choked with snow. Flood forecasting for this break-up period depends more on the knowledge of

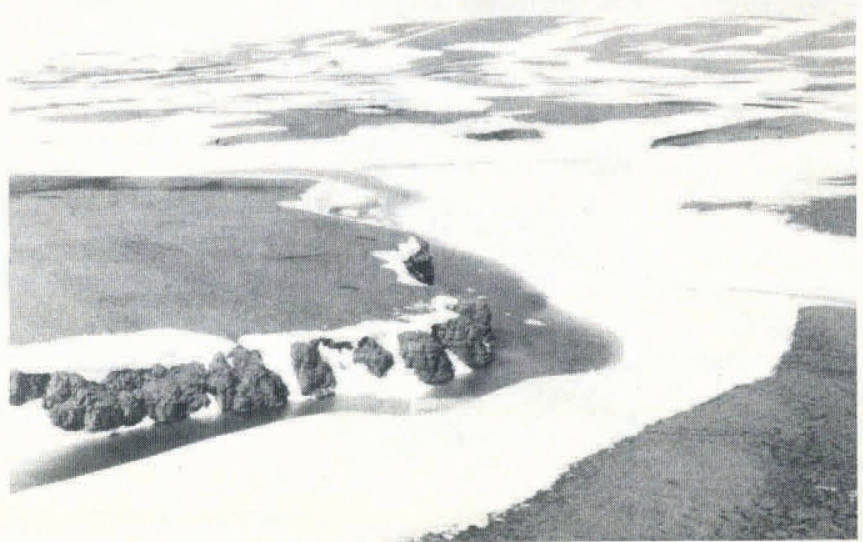

Fig. 10. Occurrence of high flow in a snowfilled valley after breaching of snow dams. Note that snowmelt has passed its peak as many slopes are bare.

the channel processes than on the basin snowmelt processes. It is in this context that a theoretical study of the snow-dam decay processes finds its major applications.

\section{ACKNOWLEDGEMENTS}

This research was funded by the Natural Sciences and Engineering Research Council of Canada and the Northern Training grant from the Department of Indian and Northern Affairs of Canada. We gratefully acknowledge the Polar Continental Shelf Project of the Department of Energy, Mines and Resources for logistical support:

\section{REFERENCES}

Chang, H. H. 1988. Fluvial processes in river engineering. New York, John Wiley.

Church, M. 1974. Hydrology and permafrost with reference to northern North America. In Proceedings of Workshop Seminar on Permafrost Hydrology, Canadian National Committee, IHD, Ottawa, 7 20.

FitzGibbon, J.E. and T. Dunne. 1981. Land surface and lake storage during snowmelt runoff in a subarctic drainage system. Arct. Alp. Res., 13(3), 277-285.

Heginbottom, J. A. 1984. The bursting of a snow dam, Tingmisut Lake, Melville Island, Northwest Territories. Geol. Surv. Can. Pap. 84-1B, 187-192.

Henderson, F. M. 1966. Open channel flow. New York, Macmillan.

Jumikis, A.R. 1984. Soil mechanics. Malabar, FL, Robert E. Krieger.

Marsh, P. and M.-k. Woo. 1985. Meltwater movement in natural heterogeneous snow covers. Water Resour. Res., 21(11), 1710-1716.

Mellor, M. 1963. Polar snow - a summary of engineering properties. In Kingery, W.D., ed. Ice and snow; properties, processes and applications. Cambridge, MA, M.I.T. Press, ${ }^{5}$ 28-559.

Pissart, A. 1967. Les modalités de l'écoulement de l'eau sur l'île Prince Patrick ( $76^{\circ}$ lat. $\mathrm{N}, 120^{\circ}$ long. O, Arc- 
tique Canadien). Biul. Peryglac., 16, 217-224.

Price, A. G. and T. Dunne. 1976. Energy balance computations of snowmelt in a subarctic area. Water Resour. Res., 12(4), 686-694.

Washburn, A.L. 1973. Periglacial processes and environments. London, Edward Arnold.

Weller, G. and B. Holmgren. 1974. The microclimates of the Arctic tundra. J. Appl. Meteorol., 13, 854-862.

Williams, G.P. 1957. An analysis of snow cover characteristics at Aklavik and Resolute, Northwest Territories. Nat. Res. Counc. Can., Div. Build. Res. Res. Pap. 40.

Woo, M.-k. and R. Heron. 1981. Occurrence of ice layers at the base of High Arctic snowpacks. Arct. Alp. Res., 13(2), 225-230.
Woo, M.-k. and R. Heron. 1987. Breakup of small rivers in the subarctic. Can. J. Earth Sci., 24(4), 784-795.

Woo, M.-k. and J. Sauriol. 1980. Channel development in snow-filled valleys, Resolute, N.W.T., Canada. Geogr. Ann., 62A(1-2), 37-56.

Woo, M.-k. and J. Sauriol. 1981. Effects of snow jams on fluvial activities in the High Arctic. Phys. Geogr., 2, 83-98.

Woo, M.-k., R. Heron and P. Steer. 1981. Catchment hydrology of a High Arctic lake. Cold Reg. Sci. Technol., 5(1), 29-41.

The accuracy of references in the text and in this list is the responsibility of the authors, to whom queries should be addressed.

MS received 22 November 1990 and in revised form 23 May 1991 